\title{
Nostalgia: An Attractive Theme for Marketing Researchers
}

\author{
Leila Lefi Hajlaoui ${ }^{1,2}$ \& Abderrazak Gharbi ${ }^{2}$ \\ ${ }^{1}$ College of Business and Economics, Qassim University, Saudi Arabia \\ ${ }^{2}$ Faculty of Economic Sciences and Management, El Manar University, Tunisia \\ Correspondence: Leila Lefi Hajlaoui, college of Business and Economics, Qassim university, P.O. BOX 6666- \\ Buraidah, 51452, Saudi Arabia. E-mail: lefileila@gmail.com
}

Received: November 20, 2019

Accepted: December 23, 2019 Online Published: February 21, 2020

doi:10.5539/ijms.v12n1p30

URL: https://doi.org/10.5539/ijms.v12n1p30

\begin{abstract}
The use of nostalgia in the marketing domain has been the subject of several researches about consumer behaviour in general and advertising in particular. This multi-faceted concept offers a better understanding of consumer behavior and brand preferences on one side, as well as a better understanding of the purchase intent. This paper discusses the nostalgia theories from different perspectives. It provides an overview of the contributions in the marketing domain for a better use of this concept by marketers.
\end{abstract}

Keywords: nostalgia proneness, retro marketing, etymology of nostalgia, nostalgic ad, yearning for the past

\section{Introduction}

The comprehension of the consumer behaviour and response to different stimuli is of a crucial importance for marketers. In recent years, the "retro marketing" theme become an importante topic for researchers in the domain of marketing based on the affirmation that things were better before, and that the past is synonymous of good quality of life and consumption (Camus, 2002). However, this idea of nostalgia or the yearning for the past is not new. The literature indicates the antiquity of this concept introduced for the first time by Hofer (1934) in the medical domain. At that time, the nostalgia was considered as a disease that can cause the death of the patient Hence, the integration of nostalgia in the marketing domain still relatively recent especially with the appearing of the post-modern nostalgic and regressive consumers (Babot \& Cova, 2003) and with the idea of the effect of end of the century supported by Stern (1992). It comes out that nostalgia is the desire to relive experiences stored in memory (Kessous \& Roux, 2006) allowing the individual to return to the past (Robert Demontrond \& Boulbry, 2003).

For a better comprehension of this concept, this paper reviews the most relevant literature dealing with nostalgia in order to high-light their main contributions from marketing perspective. Furthermore, we shed light on some important issues which can form the basis for future researches in this domain. The rest of this paper is organized as follows. The second section broadly discusses the etymology and development of the concept of nostalgia. Section three provides the characteristics of nostalgia. The fourth section puts stress on the most important contributions related to consumer behaviour. Section five provides the literature review supporting the effect of nostalgic advertisement on consumers. Finally, section six concludes the paper and highlights the futurs perspectives of the nostalgia theory.

\section{Etymology and Development of the Concept of Nostalgia}

In the Greek literature, nostalgia is composed of two words which are nostos (meaning the return) and algos (meaning the pain) that signify homesickness (Vignolles, 2004). The literature revealed that the first use of nostalgia was in the medical domain. Infact, Hofer (1934) argued that nostalgia comes out after a disturbance of the imagination, causing a nervous tension who takes always a single direction in the brain and triggers one and the same idea namely the desire to return to the homeland. All the literature of the 17th century considered the nostalgia as a morbid pathology corresponding to an extreme home sickness, an exaggerated melancholic state due to the distance from the environment in which the individual lived in the past. This irresistible desire to return could even cause the death of nostalgic individual (Vidal, 1803). So that, nostalgia was considered for long time as a type of a psychic disorder due essentially to amorous melancholy resulting from the distance from the accustomed environment or belonging. This idea corroborates the idea of returning to the homeland and the feeling of bitterness due to remoteness (Evrard, 1994). Patients "go astray in sadness" and suffer from several 
psychological disturbances that can affect some physiological functions of the body causing insomnia, fever, diarrhea, cough, hunger, decreased sensory skills and a general weakening felt by the nostalgic person. It seems that nostalgia can cause death if the patients are not brought home (Divard \& Robert-Demontrond, 1997).

By the end of the 18th century, Kant (1798) used the concept of nostalgia to regret something lost in the past instead of regretting the homeland. He argued that homesickness is the effect of missing places where the individual enjoyed the simplicity and the pleasures of life (quoted by Kessous, 2009). The existing literature on nostalgia indicated that this pionner contribution leads to the interpretation of nostalgia by many authors and philosophers of the Enlightenment, but the use of this concept remained too limited (Kessous, 2009).

Then, in the 19th century, others doctors tried to find a direct link between nostalgia and the death of the individuals suffering from this pathology. In fact, they made autopsies on the corpses of the nostalgic soldiers and they discovered obvious traces of irritation to the anterior and superior part of the brain (Berce, 1987) that leads to think about the negative implication of nostalgia on soldiers.

After that, the concept of nostalgia came out of the medical domain and appears in the sociology domain by the end of the 20th century. The existing literature indicated that the first use of nostalgia in the sociology was related to Davis (1979) study. This auther specified the nostalgia as a positive evocation of a past lived in a context of negative feelings towards the present or the impending circumstances. From Davis's (1979) point of view, the geographic mobility experienced by the population towards the end of the 20th century made individuals less likely to suffer from the feeling of uprooting and homesickness. This author supposed that nostalgia is the mechanism that would be helpful for individuals in order to maintain their identity with all the major transitions that mark the changes in the stages of the human life cycle (from childhood, adolescence to adulthood, or celibacy to married life, etc.) and it would help to compensate for the feelings of apprehension or anxiety associated with them. In other words, this author emphasizes the maintenance of the identity of the individual when evoking their idealized past (Davis, 1979).

Subsequently, the concept of nostalgia becomes popular and appears in the dictionary of the French Academy. It describes a feeling of sadness, regret and boredom. Successively, the Larousse dictionary (1991) proposed the following definition of nostalgia: "a vague sadness caused by the distance of what one has known, by the feeling of a past, by an unsatisfied desire". In addition, Le Petit Larousse (2010) dictionary added that nostalgia is " $a$ sadness and a state of languor caused by the remoteness of the native country, homesickness."

Admitting that nostalgia has been treated from medical and sociological perspective, the pionner investigation done by Holbrook (1993) high-lighted the possible application of nostalgia in the marketing domain. After that, many authors recognized nostalgia as a topic of great significance in marketing. Subsequently, each author has advanced a definition of this concept in marketing that seems to be divergent to the point that there is no univocal and widely accepted definition of nostalgia which caused some confusions and conceptual ambiguities.

\section{Definitions of Nostalgia in Marketing}

The integration of the concept of nostalgia in the marketing domain is relatively recent, coinciding with the post-modern conception of nostalgic and regressive consumers (Babot \& Cova, 2003) and with what authors like Stern (1992) calls "the end-of-the-century effect" which has encouraged the development of nostalgic behaviour among consumers. Indeed, literature on nostalgia showed that several authors have been interested in the study of this concept for several purposes. Some of them investigated the nostalgia for strategic and/or tactical purposes like Gouteron (2004), Kessous and Roux (2006). It appeared that nostalgia is a strategic positioning element present in the overall mix-marketing. Among others, Robert-Demontrond and Boulbry (2003) considered nostalgia as a desire to relive experiences heavily loaded with memories allowing the consumer to return to the past.

The literature indicated different definitions of nostalgia. Belk (1990) defined nostalgia as a melancholy mood that can be caused by an object, a scene, an odor, or a piece of music. This author evoked the melancholy dimension and highlighted the objects evocative of nostalgia and seems to complete the earlier definition advanced by Davis (1979). Hence, Holbrook and Schindler (1991) argued that nostalgia is a preference for objects that were more common or popular when the individual was young (early adulthood, adolescence) to childhood or even before birth.

Further, Bellelli (1991) demonstrate that nostalgia as emotion fall into two broad categories which are the emotion of desire and absence meaning that the individual wants to have a loved object, wants to relive an affection from the past or to find himself in a place from the past that can no longer be reached. The second category is the emotion of memory based on the impression that the individual can live what he has lost in the 
past and that he cannot live again in the present. More precisely, Stern (1992) explained that nostalgia is the emotional state in which an individual yearns for an idealized vision of a bygone era.

To deal with these issues, Baker and Kennedy (1994) came up with a new theory by putting stress on the sweet-bitter sentimental desire for a past experience, product or service. Authors like Divard and Robert-Demontrond (1997) and Madrigal and Boerstler (2007) joined this new definition of nostalgia and added the fact that nostalgia is a bitter-sweet affective reaction, possibly associated with a cognitive activity, which is experienced by an individual when an external or internal stimulus has the effect to transpose a period or an event resulting from an idealized past, whether or not part of one's own experience.

This idea was extended later by many others authors and argued that nostalgia could be a mixure of positive feelings, complex mood and emotions directed towards everything that comes from the past (people, places, objects, experiences, etc.) and that helps to define what we are currently (Holak \& Havlena, 1991, 1992; Summers, Johnson, \& McColi-Kennedy, 2001).

In summary, it appears that the diverse definitions of nostalgia on the literature overlap at the level of "Reliving the past", but they differ in the specification of the nature of the concept (mood, sensation, preference, emotion or even a desire). Nevertheless, Todorova (2010) underlined that nostalgia does not necessarily indicate a desire to relive the past, and gives the example of the former communist countries where nostalgia did not imply a desire to go back but rather a complex process of healing or a process of acceptance of the contemporary era, especially for young people.

\section{Characteristics of the Concept of Nostalgia}

Earlier studies suggest three fundamental characteristics of nostalgia:

\subsection{A Concept with a Temporal Rather than a Geographical Dimension}

Kessous (2009) indicate that the concept of nostalgia is composed of two sensations that are pain and return to homeland. However, the pain is not the result of the detachment of the homeland but is qualified as a pain of getting together one more time. This author explained that individuals who have "Heimweh" (or nostalgia for the country) when theycome back to their native country, they are very disappointed in their expectation but at the same time cured. They have the impression that in the country everything has changed (Bolzinger, 1998).

Similarly, Boda (1999) noted that the nostalgic feeling increased with disappointment, as if it had finally lost, or really lost, or definitely lost. The author concluded that the individual sadly realized that object left in a specific place in space, was lost with time.

It appears that the geographical dimension commonly known as the regret of the native country tends to disappear in favor of the temporal dimension, which is melancholy regret of something gone or that we did not know (Le Petit Robert, 1997). Indeed, nostalgia for the native country is only a pretext and a symbolic and metaphorical location of an indeterminate desire (Jankélévitch, 1996). So, the real cure for nostalgia is not a return to space, but a reduction in time, which is impossible.

\subsection{A Reaction Including Personal and Impersonal Experiences}

According to Davis (1979), nostalgic reminiscences can be related to personal experiences only. This idea was criticized by several researchers such as Holbrook (1994), Holak and Havlena (1991), Holbrook and Schindler (1991) and Divard and Robert-Demontrond (1997). These authors believe that the condition of personal experience must be removed from the definition of nostalgia. In other words, individuals can feel nostalgia for an event in which they were present (personal nostalgia), but they may also feel nostalgia for a situation they have never experienced (impersonal nostalgia).

Based on this idea, Havlena and Holak (1996) used a projective study to demonstrate that individuals may feel nostalgia for experiences they have not experienced directly. In fact, those authors use the image collage approach as a method of introspection of nostalgic experiences. They interviewed 20 students in 4 different groups. They were asked to represent the nostalgic sensation using images that they get from magazines. As part of this study, one of the four student groups, evokes his nostalgia for a period of American history that they have never experienced. This observation defends the idea of the integration of non personal experiences into the definition of the current concept of nostalgia.

\subsection{A Cognitive and Emotional Reaction}

Many authors such as Holak and Havlena (1991, 1992) and Hirsch (1992) have emphasized that nostalgia is a process of filtering negative experiences. The individual thus keeps in memory an idealized past rather than a 
real one. This past can be totally purged of any negative aspect. Hirsh (1992) cited in his study that children of alcoholic's person for example, marry people with this disorder not because they lived a happy childhood but in order to recreate an idealized childhood stored in their minds.

Moreover, if nostalgia corresponds to a selective and transformative memorization (by idealizing memories), it would also create memories. According to Werman (1976), nostalgic places or events have very often really existed, but they can also be derived from myth, from literature or totally imagined.

For instance, Davis (1979) distinguished three levels of nostalgic experience for which the degree of cognitive activity differs:

- Simple or first-rate nostalgia: This is a simple "sentimentalization" without any cognitive activity. It is a desire to find the good old days, without worrying about anything else.

- Reflective or second-rate nostalgia: The individual doubts his perception of the subject, source of nostalgia, and wonders if it was so really. Then, he proceeded to a conscious and critical investigation of the data he has buried in his memory.

- Interpreted or third-order: The individual goes to a higher level and seeks to understand why he has such a reaction. For this purpose, he operates through an analytical exploration of his nostalgic experience itself.

However, nostalgia is also an affect of positive and negative dimensions. It is widely known that nostalgia is an ambivalent concept (Werman, 1976; Roderick, 1985; Bellelli, 1991; Holak \& Havlena, 1991; Baker \& Kennedy, 1994; Divard \& Robert-Demontrond, 1997). Indeed, its positive dimension corresponds to the possibility of reliving, through memory, good and/or bad events transformed into good old days or yearning for the past. Its negative dimension reposes on the pain felt by the individual due to the impossibility to live another time these events (Belk, Wallendorf, \& Sherry, 1989; Hirsch, 1992; Holak \& Havlena, 1991).

According to Werman (1976), Kaplan (1987) and Jankélévitch (1996), time is irreversible making people unable to reverse the time and that would be the principal cause of nostalgia. The individual who does not have the power to resurrect events from the past senses unsustainable feelings of loss.

Hence, Holak and Havlena (1992) showed the presence of both positive and negative dimensions in nostalgic reminiscences. The results of their study exposed that positive emotions of warmth, joy, gratitude, affection and innocence tend to be associated with nostalgic experiences. These pleasant reminiscences would also be related to a more negative dimension when the individual realizes that the past cannot be recreated, which seems to indicate the correlation among sadness and desire.

Conversely, the literature does not all agree with this idea of ambivalence. Indeed, some authors think that nostalgia can be simultaneously positive and negative (Werman, 1976; Roderick, 1985; Holak \& Havlena, 1991; Baker \& Kennedy, 1994). In fact, Bellelli (1991) argues that desire and memory are two components of nostalgia. One is a positive experience since it brings satisfactions (nostalgia of memory) while the other is only negative due to the feeling of loss of the loved object (nostalgia of desire).

\section{Nostalgia and Consumer Behaviour}

The viewpoints on nostalgia are very diverse but they all consider nostalgia as a key concept for understanding customer behaviour. For instance, Hirsh (1992) discussed some recent theoretical thinking regarding nostalgia and olfactory stimuli. He questioned 989 people about smells recalling their childhoods. This author found that artificial and food odors cause nostalgia for young individuals, not like the mature (under 60) who were more sensitive to natural odors. Interestingly, the author found that seniors (60 years old and over) seems to be insensitive to nostalgia for smells. To complete those results, Holak and Havlena (1992) tried to understand the nature of the nostalgic reminiscences. For this purpose, 164 descriptions of nostalgic reminiscences were the subject of a content analysis. Results indicated that the majority of reminiscences are related to family, objects, people and specific events of the past such as marriage, birth etc.

Besides, many authors like Holbrook (1993) and later Holbrook and Schindler (1994) tried to measure nostalgia proneness through the examination of filmographic preferences of individuals. They tested the preferences of individuals to 62 films, considering the age, gender and nostalgia proneness. A first version of nostalgia proneness index with 20 items came out and was refined after to get the 8 items version. Holbrook and Schindler (1994) pointed that the nostalgia proneness has a moderating role since it leads individuals to formulate preferences prior to the sensitivity zone, which is 14 years on average. And it seems that men are more sensitive than women to nostalgia proneness. 
Those results were extended by Rindfleisch, Freeman et Burroughs (2000). In fact, based on the previous sdudy of Holbrook (1993), those authors used the proneness index to test the relationship between nostalgia, materialism and preferences for car brands. They exposed 141 students to two car brands (nostalgic and materialistic) and found that the nostalgic consumer cannot be sensitive to products representing materialism. Admitting those results, Holbrook and Schindler (2003) investigate another time the relation among car style preference and nostalgia with the introduction of moderating variable such as age and gender. Using the proneness index of nostalgia (Holbrook, 1993), McKenzie scale (1986) and the scale of experiments of Taylor and Konard (1980), they interviewed 225 individuals on car photographs dating from 1915-1994. The age of individuals was between 16 and 92 years old. The nostalgia proneness appeared as a moderating variable. It came out that Men's behaviour was different from women, and an area of sensitivity was identified around the age of 16 (Holbrook, 1993).

Furthermore, several studies dealt with different use of nostalgia such as the study of the effect of nostalgia experience after museum visit (Goulding, 2001). This author determined two types of behaviours namely aesthetics and existences that gave the quality of social roles, the perception of the present and social contact. Moreover, author such as Kessous (2009) tried to find a significant relation between nostalgic brand, brand attachment, connection to self-concept and purchase intent. For this purpose, she made three separate studies (semiotics and longitudinal analysis were completed by quantitative analysis). Many measurements were done using exsiting scales in the literature (Lacoeuilhe scale, 2000, the self-brand connection scale of Escalas and Bettman, 2003, Juster scale, 1966). This author highlighted the relationship between nostalgia and brand attachment and confirmed the link among nostalgia connections to the self-concept and concluded her study by giving general remarks concerning a possible typology of nostalgic moments (Kessous, 2009).

Recently, Ergin and Şahin (2019) pointed out the problem of purchasing preference related to nostalgic brands. The results showed that the participants to the study had positive preferences for nostalgic services \& nostalgic brands and positive attitudes towards purchasing them. This positive relationship was observed independently from age and gender.

\section{The Use of Nostalgia in Advertisement}

Among those who justified the application of nostalgia in advertisement, Stern (1992) conducted a literary criticism to analyze the use of nostalgia in magazine advertising and highlighted two types of nostalgia called personal and historical. This pionner study encouraged other authors to investigate this research track. In fact, Baker and Kennedy (1994) concentrated their efforts to the comprehension of the attitude towards the advertisement and the measurement of the nostalgia felt during an exhibition. For this aim, 86 students were exposed to a nostalgic press advertisement in order to measure the nostalgic reaction and appreciation of the ad. It turns out that the nostalgic reactions to the advertisement are distinct from the affective evaluation of it, even if these two constructs are positively and strongly correlated. They concluded that nostalgia may not be felt if the individual does not appreciate the advertisement. After that, Havlena and Holak (1996) established the first measurement of the emotional components of nostalgic reminiscences. So, they analysed the emotional content of 164 nostalgic reminiscences extracted from the PAD of Russel and Mehrabian (1974) and SEP of Holbrook and Batra (1987). The results indicated that nostalgic reminiscences are associated with combination of positive and negative emotions such as gratitude, sadness, desire, warmth and exaltation.

Moreover, Pascal, Sprott et Muelhing (2002) put stress on nostalgia evoked by the advertisement and responses to the ad. For this purpose, 147 students were exposed to 2 black and white magazine ads (Toshiba and Kodak brands) and the authors tried to measure the evoked nostalgia, the purchase intent and the attitudes toward the brand and the ad. It appears that if the ad evokes nostalgia, this implies a favorable perception of the brand and a greater probability of purchase. Those results are in line with Pérrusson (2003) who focused on her study on many variables such as evoked nostalgia by the ad, involvement in the product category, response to the ad and the process of persuasive advertisement. Many scales were used and retrieved from the literature (Strazzieri, 1994; Derbaix \& Pérrusson, 2003). This author conducted an experiment and 476 individuals between the ages of 18 and 78 were exposed to an ad included in a program for AURORA (car), CARSON (men's clothing) and CITTERIO (meat) brands. The moderating role of the nostalgia proneness was once again verified. It seems that the differences observed according to the nostalgic temperament are not significant as the attitude towards brand and ad, beliefs about the ad, and purchase intent.

Similarly, Lefi hajlaoui and gharbi (2017) considered the capacity of an ad to evoke nostalgia as a determinant of purchase intent. Indeed, those authors made many measurements using the existing literature (Pérrusson, 2003; Boulbry, 2003; Derbaix, 1995; Fine Falcy, 1997; Helme-Guizon, 1997) and questioned 225 consumers after 
being exposed to $\mathrm{Tv}$ ad evoking nostalgia. This study confirmed the existence of a direct and positive effect between capacity of an ad to evoke nostalgia and nostalgic affective reactions. Indeed, the positive and direct effect of nostalgic affective reactions on the attitude towards the ad and towards the brand has been established. They concluded that if an individual feels nostalgia after exposure to a nostalgic ad, this will imply a strong purchase intent of the promoted brand.

Other authors concentrated their interest on the comprehension of nostalgic advertising effects. By using past brand attachment items adapted from those recently appearing in the brand equity literature (Park et al., 2010; Thomson, MacInnis, \& Park, 2005), Muehling et al. (2014) found that the effect of nostalgia on brand-focused outcomes (purchase intent and brand attitude) are most pronounced for person who have had some past personal association with the promoted brand. However, this effect was not observed for ad-focused responses (ad involvement and attitude toward the ad). They concluded that a nostalgic ad produced more favorable responses than the non-nostalgic ad, irrespective of participant's past association with the brand. Besides, Ju et al. (2016) examined the effects of nostalgic marketing on consumer decisions, including the relation of nostalgia to perceived self-continuity, brand attitude, and purchase intent (Drolet et al., 2007; Muehling et al., 2014; Sedikides et al., 2015). A total of 199 participants completed the experiment (i.e., nostalgic advertising-sunscreen). The results indicated that nostalgic past-focused ad (as compared to present-focused ad) elicited higher perceived self-continuity which led to more favorable ratings of brand attitude and greater intent to purchase the product. A confirmatory analysis showed that the relation of advertising-evoked nostalgia to brand attitude is partially mediated by consumer's perceived self-continuity and that brand attitude is directly predicted to purchase intent.

Based on these studies, it has been noticed that there is a lack of insight regarding the impact of subjective age and nostalgic advertising style. Through the literature review, we found only one research published by boulbry (2003) dealing with these variables. This author found that advertising style has a significant influence on advertising effectiveness especially in the case of nostalgic advertising style wich seems to have a positive influence on beliefs about the product's appearance, quality, and attitude to the Ad for seniors.

\section{Discussion}

This article presented a non-exhaustive literature review on nostalgia. In fact, it seems that the studies are divided in two categories. First, Anglo-Saxon researches was especially concentrated in understanding the concept of nostalgia and its antecedents. It come out that the nostalgia proneness explains the behaviour of individuals. In the same perspective, many researchers have explored the relationship between nostalgia and attitude to brand, attitude to ad, consumer preferences and intent to purchase. Second, we notice that French researches were concentrated on the development, adaptation or comparison of measurement scales of nostalgia and its application in the persuasive advertising.

This article has many theoretical implications. It presents the importance of nostalgia to explain the consumer reactions and the persuasive ad scheme. Also, it recovers several studies that explored the importance of nostalgia in marketing domain. New contributions of authors last years demonstrate the growing importance of nostalgia for marketing managers. Indeed, Hallegatte and Ertz (2018) tested empirically the link between retro branded music and nostalgia proneness and concluded that nostalgia proneness moderates the effect of a retro brand and consumer reactions. Moreover, Wen et al. (2019) highlighted the importance of nostalgic emotions to create brand trust and brand attachment.

As a final point, it appears that this domain is huge but, even with extreme relevance of the concept of nostalgia and the increased progress of empirical research on this topic, we think that future researches may highlight the negative effects of nostalgia instead of being concentrated on the positive effect only. Also, this theoretical study establishes a starting point from which future scholars can explore other possible use of nostalgia such as the integration of nostalgia with digital marketing for an up to date use of this concept by marketers.

\section{Acknowledgments}

There are no grants for this study.

\section{References}

Babot, O., \& Cova, B. (2003). Néo marketing, 10 ans après : pour une théorie critique de la consommation et du marketing ré-enchanté. Revue Française de Marketing, 195, 79-94.

Baker, S. M., \& Kennedy, P. F. (1994). Death by nostalgia: A diagnosis of context-specific cases. Advances in Consumer Research, 21, 169-174. 
Belk, R. W., Wallendorf, M., \& Sherry, J. F. (1989). The Sacred and Profane in Consumer Behavior: Theodicy on the Odissey. Journal of Consumer Research, 16(1), 1-38. https://doi.org/10.1086/209191

Belk, R. W. (1990). The Role of Possessions in Constructing and Maintaining a Sense of Past. Advances in Consumer Research, 17, 669-676.

Belleli, G. (1991). Une émotion ambiguë : la nostalgie. Les Cahiers Internationaux de Psychologie Sociale, 11, 59-76.

Berce, Y. M. (Ed.) (1987). Nostalgie et mutilations: Psychoses de la conscription. Paris, Imago.

Boda, A. (1999). La nostalgie, exil. Évolutions Psychiatriques, 64(2), 271-279. https://doi.org/10.1016/S0014-3855(99)80065-6

Bolzinger, A. (1998). Freud, Flaubert et le circonscrit nostalgique, entre surprise et déception. Revue Freudienne, $65,19-29$.

Boulbry, G. (2003). L'impact du vieillissement cognitif sur l'efficacité publicitaire : le cas de la publicité à évocations nostalgiques. Thèse de Doctorat en Sciences de Gestion (université de Rennes), 1, 1-570.

Camus, S. (2002). Les mondes authentiques et les stratégies d'authentification: analyse duale consommateurs/distributeurs. Décisions Marketing, 26, 37-45.

Davis, F. (1979). Yearning for yesterday: A sociology of nostalgia. New York Free Press.

Derbaix, C. (1995). L'impact des réactions affectives induites par les messages publicitaires : une analyse tenant compte de l'implication. Recherche et Applications en Marketing, 10(2), 4-29. https://doi.org/10.1177/076737019501000201

Divard, R., \& Robert-Demontrond, P. (1997). La nostalgie : un thème récent dans la recherche en marketing. Recherche et Applications en Marketing, 12(4), 41-61. https://doi.org/10.1177/076737019701200403

Drolet, A., Williams, P., \& Lau-Gesk, L. (2007). Age-related differences in responses to affective vs rational ads for hedonic vs utilitarian products. Marketing Letters, 18(4), 211-221. https://doi.org/10.1007/s11002-007-9016-z

Ergin, A. E., \& Şahin, N. (2019). Why Does Nostalgia Marketing Resonate So Much with Today's Consumers: An Applied Study in Ankara. Third Sector Social Economic Review, 54(3), 1189-1206.

Escalas, J. E., \& Bettman, J. R. (2003). You are what they eat: the influence of reference groups on consumers' connections to brands. Journal of Consumer Psychology, 13(3), 339-348. https://doi.org/10.1207/S15327663JCP1303_14

Evrard, E. (1994). La nostalgie: une maladie qui se meurt. Sa signification dans l'histoire de la médecine militaire. Annales de Médecine Militaire Belge, 8(1), 21-29.

Fine Falcy, S. (1997). Les processus d'influence publicitaire : un essai de modélisation intégrant implication vis à vis de la publicité, caractéristiques psychologiques et publicitaires. Thèse de doctorat en sciences de gestion, université Aix en provence

Gouteron, J. (2004). L'utilisation de la nostalgie en segmentation: l'effet médiateur de l'âge sur la consommation d'internet : Etude comparative de l'âge chronologique et de l'âge subjectif. La Revue des Sciences de Gestion, Direction et Gestion, 39(208-229), 81-94. https://doi.org/10.1051/larsg:2004026

Hallegatte, D., \& Ertz, M. (2018). Blending the past and present in a retro branded music concert: the impact of nostalgia proneness. Journal of Product \& Brand Management, 27(5), 484-497. https://doi.org/10.1108/JPBM-08-2017-1546

Havlena, W. J., \& Holak, S. L. (1996). Exploring nostalgia imagery through the use of consumer collages. Advances in Consumer Research, 23, 35-42.

Helme-Guizon, A. (1997). Image, imagerie mentale et effets de la communication persuasive : application à une ouvre d'art incluse dans une annonce publicitaire. Thèse de doctorat, Université Paris IX Dauphine.

Hirsh A., R. (1992). Nostalgia: A neuropsychiatric understanding. Advances in Consumer Research, 19, 390-395.

Hofer, J. (1934). Medical dissertation on nostalgia (C. K. Anspach, Trans.). Bulletin of the History of Medicine, 2, 376-391. (Original work published 1688).

Holak, S. L., \& Havlena, W. J. (1991). The good old day: Observations on nostalgia and its role in consumer 
behavior. Advances in Consumer Research, 18, 323-329.

Holak, S. L., \& Havlena, W. J. (1992). Nostalgia: An exploratory study of themes and emotions in the nostalgic experience. Advances in Consumer Research, 19, 380-387.

Holbrook, M. B. (1993). Nostalgia and Consumption Preferences: Some Emerging Patterns of Consumer Tastes. Journal of Consumer Research, 20(2), 245-256. https://doi.org/10.1086/209346

Holbrook, M. B. (1994). Nostalgia proneness and consumer tastes (2nd ed.). Englewood Cliffs, New Jersy, Prentice Hall.

Holbrook, M. B., \& Batra, R. (1987). Assessing the Role of Emotions as Mediators of Consumer Responses to Advertising. Journal of Consumer Research, 14(3), 404-420. https://doi.org/10.1086/209123

Holbrook, M. B., \& Schindler, R. M. (1991). Echoes of the Dear Departed Past: Some work in Progress on Nostalgia. Advances in Consumer Research, 18, 330-333.

Holbrook, M. B., \& Schindler, R. M. (1994). Age, Sex, and Attitude toward the Past as Predictors of Consumer's Aetsthetic Tastes for Cultural Products. Journal of Marketing Research, 31, 412-422. https://doi.org/10.1177/002224379403100309

Holbrook, M. B., \& Schindler, R. M. (2003). Nostalgic bonding: Exploring the Role of Nostalgia in the Consumption Experience. Journal of Consumer Behavior, 3(2), 107-127. https://doi.org/10.1002/cb.127

Jankelevitch, V. (1996). L’irréversible et la nostalgie. Paris, Flammarion.

Ju, I., Kim, J., Chang, M. J., \& Bluck, S. (2016). Nostalgic marketing, perceived self-continuity, and consumer decisions. Management Decision, 54(8), 2063-2083. https://doi.org/10.1108/MD-11-2015-0501

Juster, T. F. (1966). Consumer Buying Intentions and Purchase Probability: An Experiment in Survey Design. Journal of the American Statistical Association, 61(315), 658-696. https://doi.org/10.1080/01621459.1966.10480897

Kant, E. (1798). Anthropologie du point de vue pragmatique. Euvres philosophiques, tome 3, Paris, Gallimard.

Kaplan, K. J. (1972). From Attitude Formation to Attitude Change: Acceptance and Impact on Cognitive Mediators. Sociometry, 35(3), 448-467. https://doi.org/10.2307/2786505

Kessous, A. (2009). Nostalgie et relations des consommateurs aux marques: contributions théoriques et implications managériales. Thèse de doctorat en sciences de gestion, IAE Aix-en-provence.

Lacoueilhe, J. (2000). Le Concept d'Attachement : Contribution à l'Etude du Rôle des Facteurs Affectifs dans la Formation de la Fidélité à la Marque. Thèse de Doctorat en Sciences de Gestion, ESA Université Paris XII.

Lefi Hajlaoui, L., \& Gharbi, A. (2017). Effet de la capacité d'une annonce à évoquer la nostalgie sur l'intention d'achat du produit: un essai de modélisation. La Revue Gestion et Organisation, 9(2), 124-130. https://doi.org/10.1016/j.rgo.2017.04.002

MacKenzie, S. B., Lutz, R. J., \& Belch, G. E. (1986). The Role of Attitude toward the Ad as a Mediator of Advertising Effectiveness: A Test of Competing Explanations. Journal of Marketing Research, 23, 130-143. https://doi.org/10.1177/002224378602300205

Mehrabian, A., \& Russel, J. A. (1974). An approach to environmental psychology. Cambridge, MIT Press.

Muehling, D. D., \& Pascal, V. J. (2011). An Empirical Investigation of the Differential Effects of Personal, Historical, and Non-Nostalgic Advertising on Consumer Responses. Journal of Advertising, 40(2), $107-122$. https://doi.org/10.2753/JOA0091-3367400208

Muehling, D. D., Sprott, D. E., \& Sultan, A. J. (2014). Exploring the Boundaries of Nostalgic Advertising Effects: A Consideration of Childhood Brand Exposure and Attachment on Consumer's Responses to Nostalgia-Themed Advertisements. Journal of Advertising, 43(1), $73-84$. https://doi.org/10.1080/00913367.2013.815110

Pascal, V. J., Sprott, D. E., \& Muehling, D. D. (2002). The Influence of Evoked Nostalgia on Consumers' Responses to Advertising: An Exploratory Study. Journal of Current Issues and Research in Advertising, 24(1), 39-49. https://doi.org/10.1080/10641734.2002.10505126

Pérrusson, C. (2003). Etude des effets de la nostalgie évoquée dans le message publicitaire sur les réponses des consommateurs. Actes des 8ème journées de recherche en marketing de Bourgogne. Retrieved from ftp://ungaro.u-bourgogne.fr/filser/actesnov2003.pdf 
Rindfleisch, A., \& Sprott, D. E. (2000). Moving Forward on Looking Backward: Advancing Theory and Practice in Nostalgia. Advances in Consumer Research, 27, 34-35.

Robert-Demontrond, P., \& Boulbry, G. (2003). Marketing mémoriels: attraits et dangers du phénomène nostalgique. Gestion, 2, 31-47.

Roderick, P. (1985). Reflections on the origin and aim of nostalgia. Journal of Analytical Psychology, 30, 135-148. https://doi.org/10.1111/j.1465-5922.1985.00135.x

Sedikides, C., Wildschut, T., Routledge, C., \& Arndt, J. (2015). Nostalgia counteracts self-discontinuity and restores self-continuity. European Journal of Social Psychology, 45(1), 52-61. https://doi.org/10.1002/ejsp.2073

Stern, B. B. (1992). Historical and personal nostalgia in advertising text: The fin de siècle effect. Journal of Advertising, 21(4), 11-22. https://doi.org/10.1080/00913367.1992.10673382

Strazzieri, A. (1994). Mesurer l'implication durable vis-à-vis d'un produit indépendamment du risque perçu. Recherche et Applications en Marketing, 9(1), 73-91. https://doi.org/10.1177/076737019400900104

Summers, J., Johnson, M., \& Janet, J. (2001). Evoking the Past: Exploring Nostalgia's Relevance to Sport Consumption. Asia Pacific Advances in Consumer Research, 4(1), 108-113.

Taylor, M. S., \& Konard, V. A. (1980). Scaling Dispositions toward the Past. Environment and Behaviour, 12(3), 283-307. https://doi.org/10.1177/0013916580123001

Thomson, M., MacInnis, D. J., \& Whan Park, C. (2005). The Ties That Bind: Measuring the Strength of Consumers' Emotional Attachments to Brands. Journal of Consumer Psychology, 15(1), 77-91. https://doi.org/10.1207/s15327663jcp1501_10

Todorova, M. (2010). From Utopia to Propaganda and Back in Post-Communist Nostalgia. New York: Berghahn Books. https://doi.org/10.2307/j.ctt9qd8t4

VIDAL, F. (1803). De l'influence de quelques maladies de l'âme sur l'économie animale. Thèse de doctorat de médecine, Montpellier.

Vignolles, A. (2004). Nostalgie et comportement du consommateur : Test des échelles anglo-saxonnes de propension à la nostalgie dans un contexte culturel français et voies de recherche (pp. 1-25). Working paper, IAE de Toulouse.

Wen, T., Quin, T., \& Liu, R. R. (2019). The impact of nostalgic emotion on brand attachment, an empirical study from China. Asia Pacific Journal of Marketing and Logistics, 31(4), 1118-1137. https://doi.org/10.1108/APJML-09-2018-0390

Werman, D. (1976). Normal and pathological nostalgia. Journal of American Psychoanalytic Association, 25(2), 387-398. https://doi.org/10.1177/000306517702500205

Whan Park, C., Deborah, J., MacInnis, J. P., Andreas, B. E., \& Dawn, I. (2010). Brand Attachment and Brand Attitude Strength: Conceptual and Empirical Differentiation of Two Critical Brand Equity Drivers. Journal of Marketing, 74(6), 1-17. https://doi.org/10.1509/jmkg.74.6.1

\section{Copyrights}

Copyright for this article is retained by the author, with first publication rights granted to the journal.

This is an open-access article distributed under the terms and conditions of the Creative Commons Attribution license (http://creativecommons.org/licenses/by/4.0/). 